\title{
Establishing the Absolute Configuration of the Asbestinins: Enantioselective Total Synthesis of 11-Acetoxy-4- deoxyasbestinin D
}

\author{
Michael T. Crimmins ${ }^{*}$ and J. Michael Ellis \\ Department of Chemistry, Venable and Kenan Laboratories of Chemistry, University of North \\ Carolina at Chapel Hill, Chapel Hill, North Carolina 27599-3290
}

\begin{abstract}
A highly stereoselective synthesis of 11-acetoxy-4-deoxyasbestinin D (1) has been completed in 26 linear steps. The synthesis hinges on a selective glycolate aldol addition to establish the C-2 stereocenter, a ring-closing metathesis reaction to complete the oxonene, and an intramolecular DielsAlder cycloaddition to establish the relative configuration at C-1, C-10, and C14. This initial total synthesis of an asbestinin also serves to confirm the absolute configuration of this sub-class of the C2-C11-cyclized cembranoid natural products.
\end{abstract}

Synthesis of C2-C11 cyclized cembranoids has intensified over the past decade, due to their fascinating molecular topology and interesting biological properties. ${ }^{1}$ Various approaches to the syntheses of the cladiellins and briarellins have been implemented; ${ }^{2}$ however, none of the asbestinins have been prepared by total synthesis, leaving some doubt regarding their absolute configuration and biosynthetic origin. ${ }^{1 b, 3}$ In 1990, Rodríguez and co-workers isolated 11acetoxy-4-deoxyasbestinin D (1) from Briareum asbestinum, making note of its particular cytotoxicity against $\mathrm{CHO}-\mathrm{K} 1$ cells $\left(\mathrm{ED}_{50}=4.82 \mu \mathrm{g} / \mathrm{mL}\right)$ and strong anti-microbial activity against Klebsiella pneumoniae. ${ }^{3}$ The tetracyclic framework of 11-acetoxy-4-deoxyasbestinin $\mathrm{D}$ includes nine contiguous stereocenters and a fully-substituted tetrahydrofuran, rendering it a formidable and intriguing target for chemical synthesis.

We recently reported a successful strategy for the synthesis of members of the eunicellin class of cembranoids involving the construction of the oxonene ring through ring-closing metathesis, 4-6 followed by stereoselective formation of the hydroisobenzofuran via an intramolecular Diels-Alder cycloaddition. ${ }^{2 \mathrm{k}}$ The total synthesis of 11-acetoxy-4-deoxyasbestinin D (1) was undertaken with the intent of validating the intramolecular Diels-Alder approach for the synthesis of the asbestinins. ${ }^{7}$ Our synthetic plan hinged on an asymmetric glycolate aldol reaction of oxazolidinethione 4 to assemble the diene 3 , a precursor of the oxonene 2 (Scheme 1). This report describes the first total synthesis of an asbestinin verifying the absolute configuration of the sub-class.

The synthesis of the oxonene core began with the addition of isoprenylmagnesium bromide to $(R)$-benzyl glycidyl ether (5) to afford a secondary alcohol, ${ }^{8}$ which was $O$-alkylated with sodium bromoacetate (Scheme 2). The resultant glycolic acid was coupled with $(S)$-4benzyloxazolidinethione to deliver thioimide 4. Addition of 4-pentenal, ${ }^{9}$ to the chlorotitanium enolate of thioimide 4 in the presence of NMP, ${ }^{5 c, 7}$ gave syn-aldol adduct 6 in good yield and diastereoselectivity $(70 \%,>95: 5 \mathrm{dr}) .{ }^{10}$ Reductive removal of the chiral auxiliary and 
protection of the diol afforded diene 3 . As anticipated, based on previous successful metathesis reactions to form medium ring ethers, ${ }^{4-6}$ treatment of diene 3 with the Grubbs catalyst ${ }^{11}$ led to facile formation of oxonene 7 (99\% yield).

With the oxonene 7 in hand, efforts focused on construction of the required Diels-Alder precursor. To this end, the benzyl ether was reductively cleaved, and the resultant alcohol was oxidized to the aldehyde under Swern conditions (Scheme 3). ${ }^{12}$ The aldehyde was subjected to successive Wittig reactions, first using phosphorane $8^{13}$, then methylene

triphenylphosphorane to yield the requisite diene 9. Selective deprotection of the primary TBS ether was carefully carried out in the presence of the labile enol ether. ${ }^{14}$ Oxidation ${ }^{12}$ of the alcohol provided an aldehyde, which was treated with phosphorane $1 \mathbf{0}^{15}$ at elevated temperature. Subsequent to the Wittig reaction, a spontaneous Diels-Alder cycloaddition ensued through the more favorable exo transition state providing adduct $\mathbf{1 1}$ in $80 \%$ yield as a single diastereomer. Earlier work in related systems had demonstrated the importance of both the $\mathrm{C}-3$ configuration and the $\mathrm{C} 3$ hydroxyl protecting group in controlling the diastereoselectivity of the Diels-Alder reaction. $2 \mathrm{k}, 16$

Ketone 11 was converted to an alkene to introduce a handle to establish the C-15 stereocenter (Scheme 4). Deprotection and oxidation 17 of the $\mathrm{C} 3$ secondary alcohol, followed by addition of methylmagnesium chloride to the resultant ketone provided the tertiary alcohol $\mathbf{1 2}$ in excellent yield as a single isomer.

With the required tricyclic core in place, refunctionalization of the cyclohexane ring was undertaken. Acidic hydrolysis of the enol ether yielded the $\alpha$-methyl ketone (10:1 dr); however, ${ }^{1} \mathrm{H}$ NMR analysis (COSY, nOeSY) indicated the undesired isomer was the major product. This problem was easily corrected by base catalyzed equilibration to the desired isomer, to provide $84 \%$ of the desired ketone after two recycles. Reduction of the ketone with L-Selectride ${ }^{\circledR}$ yielded the secondary alcohol as a single diastereomer, which was esterified to give acetate $\mathbf{1 3}$.

The final stage of the synthesis required introduction of the $\mathrm{C}-15$ stereocenter and formation of the oxapane. The regioselective and stereoselective hydroboration of the 1,1-disubstituted olefin of diene 13 proved to be a challenge. Regioselective hydroboration occurred in high yield with 9-BBN, but the reaction was not stereoselective. ${ }^{18}$ It was speculated that increasing the steric bulk at $\mathrm{C}-3$ could impede addition from the undesired face of the alkene, improving the diastereoselection. Accordingly, the C-3 hydroxyl was protected as triethylsilyl ether 14 , but only moderate improvement in the diastereoselectivity (2:1 dr) was observed.

Fortunately, the use of (+)-diisopinocampheylborane delivered the desired alcohol $\mathbf{1 5}$ as a single isomer after oxidative workup. ${ }^{19,20}$ The triethylsilyl ether was subsequently cleaved to deliver the diol 16 in $64 \%$ yield over two steps. Taking advantage of the conditions employed by Overman in the syntheses of briarellins $\mathrm{E}$ and $\mathrm{F}, \mathrm{i}$ the diol $\mathbf{1 6}$ was treated with triflic anhydride and 2,6-lutidine to deliver 11-acetoxy-4-deoxyasbestinin D (1) in 66\% yield. Spectroscopic data for synthetic 1 matched the reported data for the natural product in all regards. ${ }^{3}$ Of particular note, the specific rotation of synthetic $\mathbf{1}$ and a purified sample of natural 1 were identical $\left([\alpha]_{\mathrm{D}}{ }^{26} ; \mathrm{CHCl}_{3} ;=-15\right)$ when measured under the conditions.

In summary, a highly stereoselective synthesis of 11-acetoxy-4-deoxyasbestinin $\mathrm{D}$ has been completed in 26 linear steps, hinging on a selective glycolate aldol addition to establish the $\mathrm{C}-2$ stereocenter, a ring-closing metathesis reaction to complete the oxonene, and an intramolecular Diels-Alder cycloaddition to establish the relative configuration at C-1, C-10, and C14. This initial total synthesis of an asbestinin also serves to confirm the absolute configuration of this family of natural products. 


\section{Supplementary Material}

Refer to Web version on PubMed Central for supplementary material.

\section{Acknowledgements}

This work was supported by a research grant from The National Institutes of Health (GM60567). We acknowledge a generous gift of $(R)$-benzyl glycidyl ether from Daiso, Inc. We also are grateful to Dr. Abimael D. Rodríguez (University of Puerto Rico, Río Piedras) for his donation of an authentic sample of the natural product.

\section{References}

1. For reviews see: (a) Rodríguez AD. Tetrahedron 1995;51:4571. (b) Bernardelli P, Paquette LA. Heterocycles 1998;49:531. (c) Sung PS, Chen MC. Heterocycles 2002;57:1705.

2. (a) MacMillan DWC, Overman LE. J Am Chem Soc 1995;117:10391. (b) Paquette LA, Moradei OM, Bernardelli P, Lange T. Org Lett 2000;2:1875. [PubMed: 10891180] (c) Overman LE, Pennington LD. Org Lett 2000;2:2683. [PubMed: 10990427] (d) Gallou F, MacMillan DWC, Overman LE, Paquette LA, Pennington LD, Yang J. Org Lett 2001;3:135. [PubMed: 11429857] (e) Bernardelli P, Moradei OM, Friedrich D, Yang J, Gallou F, Dyck BP, Doskotch RW, Lange T, Paquette LA. J Am Chem Soc 2001;123:9021. [PubMed: 11552810] (f) MacMillan DWC, Overman LE, Pennington LD. J Am Chem Soc 2001;123:9033. [PubMed: 11552811] (g) Chai Y, Vicic DA, McIntosh MC. Org Lett 2003;5:1039. [PubMed: 12659568] (h) Corminboeuf O, Overman LE, Pennington LD. Org Lett 2003;5:1543. [PubMed: 12713319] (i) Corminboeuf O, Overman LE, Pennington LD. J Am Chem Soc 2003;125:6650. [PubMed: 12769572] (j) Molander GA, StJean DJ Jr, Haas J. J Am Chem Soc 2004;126:1642. [PubMed: 14871089] (k) Crimmins MT, Brown BH. J Am Chem Soc 2004;126:10264. [PubMed: 15315437]

3. Morales JJ, Lorenzo D, Rodríguez AD. J Nat Prod 1991;54:1368. [PubMed: 1686898]

4. (a) Crimmins MT, Emmitte KA. Synthesis 2000:899. (b) Crimmins MT, DeBaillie AC. Org Lett 2003;5:3009. [PubMed: 12916968]

5. (a) Crimmins MT, Emmitte KA. Org Lett 1999;1:2029. [PubMed: 10836060] (b) Crimmins MT, Choy AL. J Am Chem Soc 1999;121:5653. (c) Crimmins MT, Tabet EA. J Am Chem Soc 2000;122:5473. (d) Crimmins MT, Cleary PA. Heterocycles 2003;61:87.

6. (a) Crimmins MT, Emmitte KA. J Am Chem Soc 2001;123:1533. [PubMed: 11456742] (b) Crimmins MT, Emmitte KA, Choy AL. Tetrahedron 2002;58:1817. (c) Crimmins MT, Powell MT. J Am Chem Soc 2003;125:7592. [PubMed: 12812500]

7. (a) Crimmins MT, King BW, Tabet EA. J Am Chem Soc 1997;119:7883. (b) Crimmins MT, Choy AL. J Org Chem 1997;62:7548. (c) Crimmins MT, King BW, Tabet EA, Chaudhary K. J Org Chem 2001;66:894. [PubMed: 11430110] (d) Crimmins MT, She J. Synlett 2004:1371.

8. (a) Lachance H, Lu X, Gravel M, Hall DG. J Am Chem Soc 2003;125:10160. [PubMed: 12926924]

(b) Hubbs JL, Heathcock CH. J Am Chem Soc 2003;125:12836. [PubMed: 14558832]

9. (a) McNeill AH, Thomas EJ. Tetrahedron Lett 1993;34:1669. (b) Farquhar D, Cherif A, Bakina E, Nelson JA. J Med Chem 1998;41:965. [PubMed: 9526570]

10. The $N$-acyloxazolidinone derivative of glycolate 4 gave a slightly higher yield, but with diminished diastereoselection $(78 \%,>90: 10 \mathrm{dr})$

11. Scholl M, Ding S, Lee CW, Grubbs RH. Org Lett 1999;1:953. [PubMed: 10823227]

12. Mancuso AJ, Huang SL, Swern D. J Org Chem 1978;43:2480.

13. Guiney D, Gibson CL, Suckling CJ. Org Biomol Chem 2003;1:664. [PubMed: 12929453]

14. Schinzer D, Bohm OM, Altmann KH, Wartmann M. Synlett 2004:1375.

15. Kuroda H, Hanaki E, Izawa H, Kano M, Itahashi H. Tetrahedron 2004;60:1913.

16. Davidson JEP, Gilmour R, Ducki S, Davies JE, Green R, Burton JW, Holmes AB. Synlett 2004:1434.

17. Dess DB, Martin JC. J Am Chem Soc 1991;113:7277.

18. Brown, HC.; Midland, MM.; Levy, AB.; Kramer, GW. Organic Synthesis via Boranes. Wiley; New York: 1975. (b) Cheng D, Zhu S, Yu Z, Cohen T. J Am Chem Soc 2001;123:30. [PubMed: 11273598] 
(c) Ebel H, Polborn K, Steglich W. Eur J Org Chem 2002:2905. (d) Miyaoka H, Honda D, Mitome H, Yamada Y. Tetrahedron Lett 2002;43:7773.

19. Brown HC, Desai MC, Jadhav PK. J Org Chem 1982;47:5065.

20. Masamune S, Lu LDL, Jackson WP, Kaiho T, Toyoda T. J Am Chem Soc 1982;104:5523. 

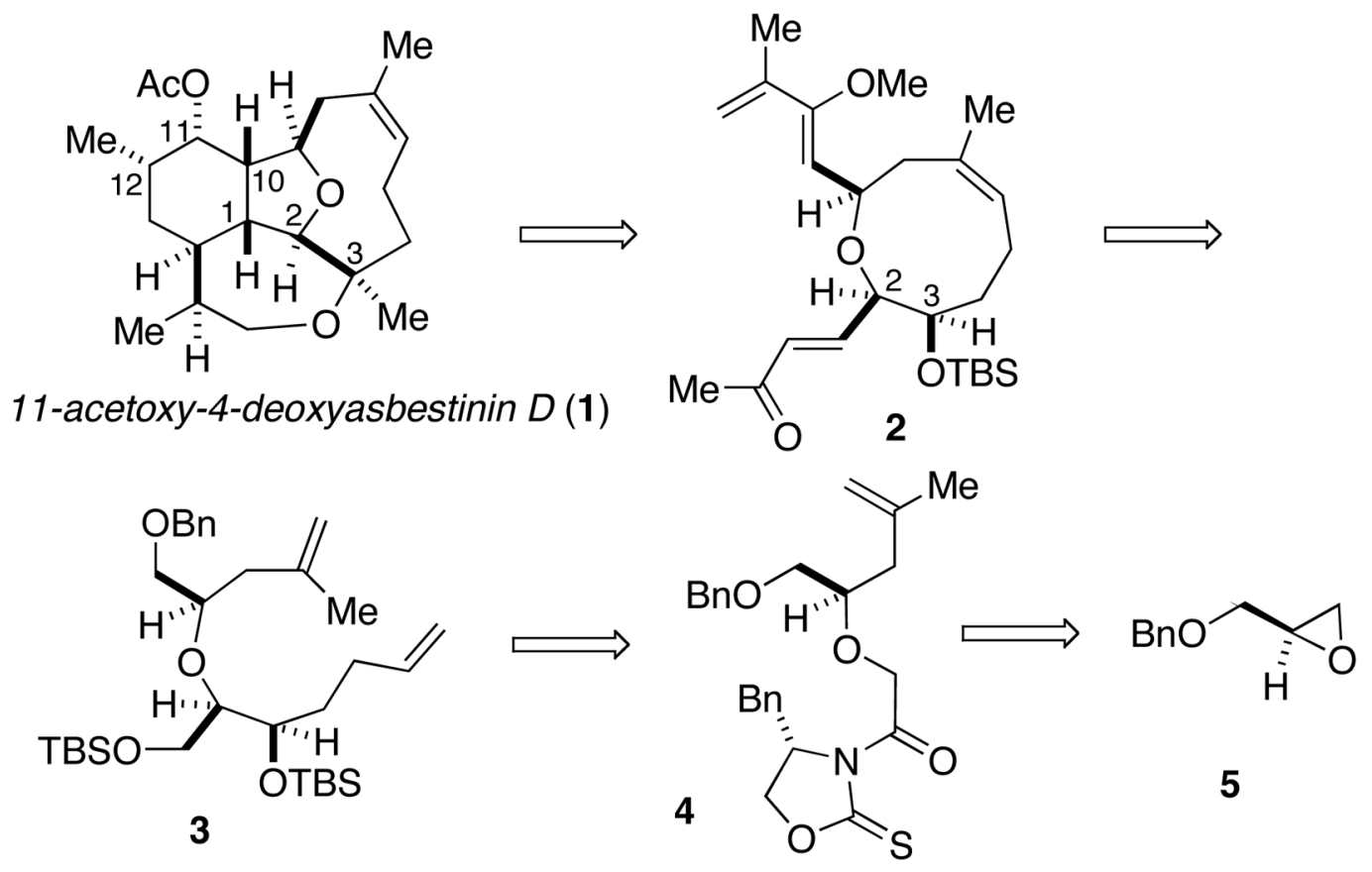

Scheme 1.

Retrosynthetic Analysis of $\mathbf{1}$ 
<smiles>C=CCC[C@H](O)[C@@H](O[C@H](CCOc1ccccc1)C(=O)N1C(=S)OC[C@H]1Cc1ccccc1)C(=C)C</smiles><smiles>C=CCCC(O[Sb])C(COC(C)(C)C)OC(COCc1ccccc1)CC(=C)C</smiles>

Scheme 2.

Synthesis of the Oxonene Ring ${ }^{\text {a }}$

a (a) $\mathrm{CH}_{2}=\mathrm{C}\left(\mathrm{CH}_{3}\right) \mathrm{MgBr}$, CuI, THF, $-40{ }^{\circ} \mathrm{C}, 99 \%$; (b) $\mathrm{NaH}, \mathrm{BrCH}_{2} \mathrm{CO}_{2} \mathrm{H}$, THF, DMF, 95\%; (c) (S)-benzyl-1,3-oxazolidine-2-thione, DCC, DMAP, $\mathrm{CH}_{2} \mathrm{Cl}_{2}, 86 \%$; (d) $\mathrm{TiCl}_{4}, i$-Pr $2 \mathrm{NEt}$, NMP, 4-pentenal, $\mathrm{CH}_{2} \mathrm{Cl}_{2},-78{ }^{\circ} \mathrm{C}, 70 \%$; (e) $\mathrm{LiBH}_{4}, \mathrm{MeOH}, \mathrm{Et}_{2} \mathrm{O}, 0{ }^{\circ} \mathrm{C}, 95 \%$; (f) $\mathrm{TBSCl}$, imid., DMAP, DMF, $50{ }^{\circ} \mathrm{C}, 87 \%$; (g) $\mathrm{Cl}_{2}\left(\mathrm{Cy}_{3} \mathrm{P}\right)(\mathrm{IMes}) \mathrm{Ru}=\mathrm{CHPh}, \mathrm{CH}_{2} \mathrm{Cl}_{2}, 40{ }^{\circ} \mathrm{C}, 99 \%$. 

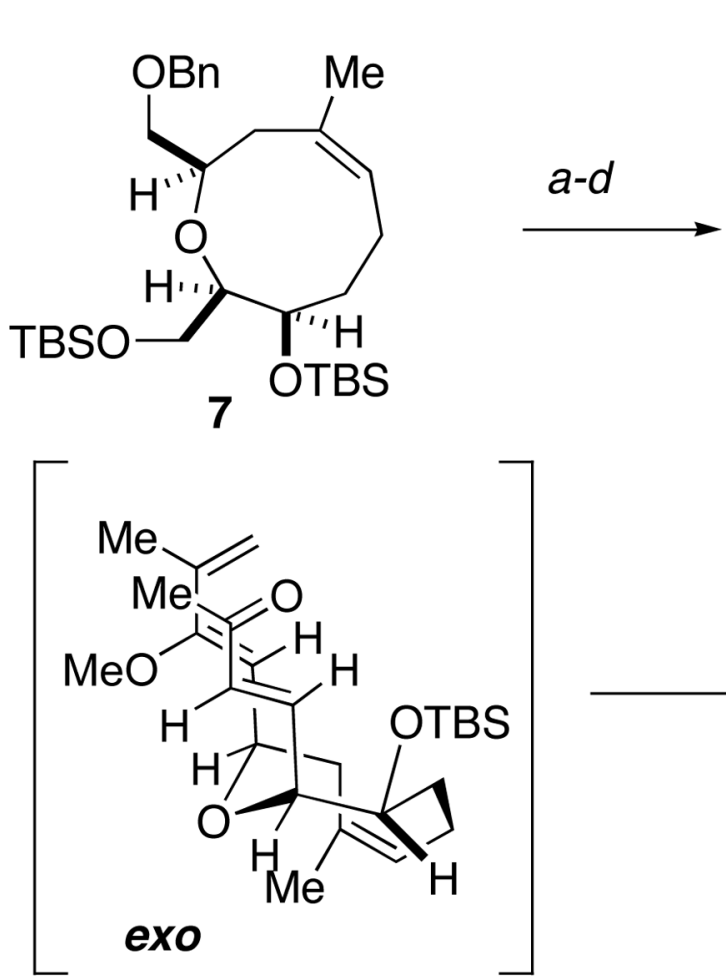

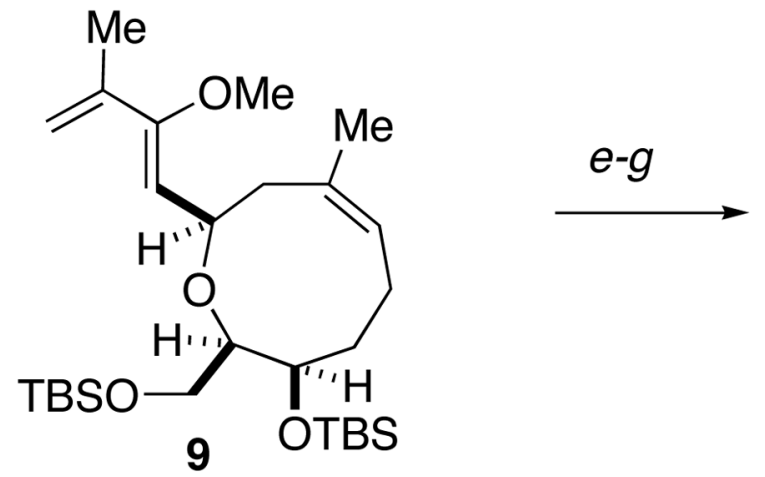

$11 \mathrm{R}=\mathrm{TBS}$

Scheme 3.

Intramolecular Diels-Alder Cycloaddition ${ }^{\mathrm{a}}$

a (a) $\mathrm{Na}, \mathrm{NH}_{3}, \mathrm{THF},-78{ }^{\circ} \mathrm{C}, 86 \%$; (b) $(\mathrm{COCl})_{2}, \mathrm{DMSO}, \mathrm{Et}_{3} \mathrm{~N}, \mathrm{CH}_{2} \mathrm{Cl}_{2},-78{ }^{\circ} \mathrm{C}$ to $0{ }^{\circ} \mathrm{C}, 94 \%$;

(c) $\mathrm{Ph}_{3} \mathrm{P}=\mathrm{C}(\mathrm{OMe}) \mathrm{C}(\mathrm{O}) \mathrm{Me}(8), \mathrm{PhCH}_{3}, 110{ }^{\circ} \mathrm{C}, 84 \%$; (d) $\mathrm{Ph}_{3} \mathrm{PCH}_{3} \mathrm{Br}, t-\mathrm{BuOK}, \mathrm{THF}, 0{ }^{\circ} \mathrm{C}$, $87 \%$; (e) $\mathrm{NH}_{4} \mathrm{~F}, \mathrm{MeOH}, 79 \%$; (f) $(\mathrm{COCl})_{2}, \mathrm{DMSO}, \mathrm{Et}_{3} \mathrm{~N}, \mathrm{CH}_{2} \mathrm{Cl}_{2},-78{ }^{\circ} \mathrm{C}$ to $0{ }^{\circ} \mathrm{C}, 93 \%$; (g) $\mathrm{Ph}_{3} \mathrm{P}=\mathrm{CHC}(\mathrm{O}) \mathrm{Me}(10), \mathrm{PhCH}_{3}, 110{ }^{\circ} \mathrm{C}, 80 \%$. 
<smiles>COC1=C(C)C[C@@H](C(C)=O)[C@@H]2[C@H](O)[C@@H](O)CC/C=C(/C)C[C@H]2O[C@H]1C</smiles>

$11 \mathrm{R}=$ TBS

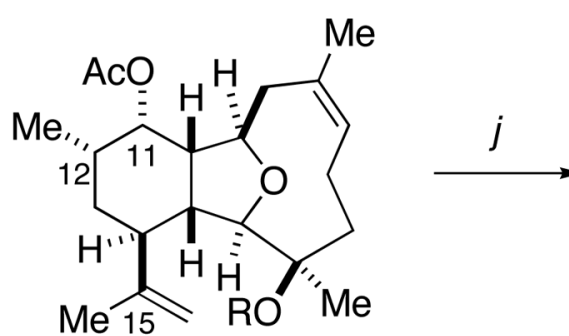<smiles>C=C(C)[C@H]1CC(C)=C(OC)[C@@H]2[C@H](C)[C@](C)(O)CC/C=C(/C)C[C@H]2O[C@H]1C</smiles>

12

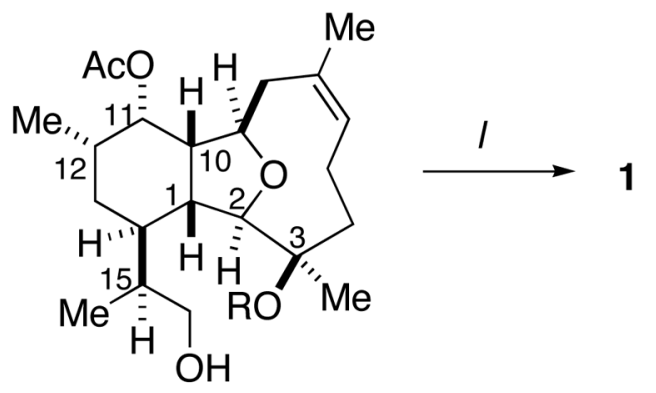

$k \longrightarrow \begin{aligned} 15, \mathrm{R} & =\mathrm{SiEt}_{3} \\ 16, \mathrm{R} & =\mathrm{H}\end{aligned}$

Scheme 4.

Completion of 11-Acetoxy-4-deoxyasbestinin $\mathrm{D}^{\mathrm{a}}$

a(a) $\mathrm{Ph}_{3} \mathrm{PCH}_{3} \mathrm{Br}$, KO- $t$-Bu, THF, $85 \%$; (b) $n$-Bu 4 NF, THF, $95 \%$; (c) Dess-Martin periodinane, pyridine, $\mathrm{CH}_{2} \mathrm{Cl}_{2}, 98 \%$; (d) $\mathrm{MeMgCl}$, THF, $0^{\circ} \mathrm{C}, 98 \%$; (e) $\mathrm{HCl}, \mathrm{CHCl}_{3}, 96 \%, 10: 1 \mathrm{dr}$; (f) $\mathrm{NaH}$, $\mathrm{MeOH}, 99 \%$, 1:1.2 dr; (g) L-Selectride ${ }^{\circledR}$, THF, $-78^{\circ} \mathrm{C}, 94 \%$; (h) $\mathrm{Ac}_{2} \mathrm{O}, \mathrm{Et}_{3} \mathrm{~N}$, DMAP, $\mathrm{CH}_{2} \mathrm{Cl}_{2}, 99 \%$; (i) TESOTf, 2,6-lutidine, $\mathrm{CH}_{2} \mathrm{Cl}_{2}, 0{ }^{\circ} \mathrm{C}, 80 \%$; (j) (+)-Ipc $2 \mathrm{BH}$, THF; $\mathrm{NaOH}$, $\mathrm{H}_{2} \mathrm{O}_{2}$; (k) n-Bu 4 NF, THF, 64\% (two steps); (l) $\mathrm{Tf}_{2} \mathrm{O}, 2,6$-lutidine, $\mathrm{CHCl}_{3}, 0{ }^{\circ} \mathrm{C}$ to $25{ }^{\circ} \mathrm{C}, 66 \%$. 